\title{
Comparative Study of Mirza Ghalib and William Wordsworth: Poets of Man and Nature
}

\author{
Dr. Shaheen Sultana \\ Associate Professor \& Head \\ Dept. of Urdu \\ Aliah University
}

\begin{abstract}
Mirza Ghalib and William Wordsworth are internationally popular poets. As far as the poet William Wordsworth is concerned he knows no introduction. The famous Urdu poet Mirza Ghalib's ghazals has been translated into fourteen world famous languages including French and Portugeese. This proves his popularity at international level. Both the world famous poets deal with humanity and nature which covers the universal matters. My research work has global relevance.
\end{abstract}

It is an accepted fact that all the literatures of the world have their base in religion, nature and humanity. The writers are deeply concerned with the beauties of nature and different perspective of humanity. English literature is one of the most popular literatures in the world. At the same time Urdu literature is gaining its world-wide popularity because of its very lovely part that is Ghazal. Ghazal has become one of the most important themes of Urdu literature. Mirza Ghalib is one of the world renowned poets of Urdu Ghazal. His popularity can be understood by the fact that his literary work Diwane-Ghalib is translated into fourteen languages of the world. His Diwane-ghalib is consisted of near about thousand couplets. All the couplets depicts moral, philosophical, Sufism, political and social aspects of humanity. But the most beautiful part of Mirza Ghalib poetry is its natural and humanistic approach. My research work has opened the new dimensions of beautiful presentation of nature and human aspects in the poetry of both the great poets. I have presented the beautiful aspects of nature and humanity from both English and Urdu literature.

I have come to the conclusion that more or less all the literatures of the world have many things in common. There are some feelings, some emotions and some values which are universal. The feelings of sorrow and happiness are common to all the people irrespective of their caste, creed and religion. The feelings of grief and happiness affect all the people in the same manner. Above all nature is for every body. No war, no bomb and no terrorist act can affect the guided functions of the moon, the sun and the stars. We cannot stop the beautiful waterfalls, neither can we can move the mountains. The comparative study of Mirza Ghalib and William Wordsworth has helped us to cherish and enjoy the feelings of humanity and nature in completely new way. Ghazals of Ghalib at one side have pleasing world of nature proving the supreme power of Almighty. Wordsworth on the other hand proving the fact that nature is no doubt beautiful but at the same time human beings are the most beautiful creation of nature. 
It is needless to say that change is taking place in all the spheres of life including science and literature. Interdisciplinary researches are becoming more popular. As I had done Master's in both Urdu and English literature, I felt it is important to bring two world famous poets, namely, William Wordsworth and Mirza Ghalib closely to the scholars of both the literatures. It is very important to note that both the poets belong to different social and cultural background yet their views regarding nature and humanity is common. I am sure this research work will help us in understanding humanity and nature from the poets of two different literary worlds.

It is an acceptable fact that all the literatures of world have many things in common. This research work will open the new dimension of research for the students of literature to compare and contrast the poets from two interdisciplinary fields. This will be helpful to the scholars of both the literary world. The scholars of Urdu literature will be more familiar about the works of William Wordsworth whereas the scholar of English literature will also come to know about the world famous poet, Mirza Ghalib whose work has been translated into fourteen different languages of the world.

It is absolutely a new area of research. Many researches have been done separately on Mirza Ghalib \& William Wordsworth as they belong to two different literary worlds. Ghalib's works have been translated into English literature. But comparison and contrast of both the famous poets will be done through my research work. I am sure that this research will itself open the new dimensions of research in the field of Urdu literature.

Mirza Ghalib and William Wordsworth are internationally popular poets. As far as the poet William Wordsworth is concerned he knows no introduction. The famous Urdu poet Mirza Ghalib's ghazals has been translated into fourteen world famous languages including French and Portugeese. This proves his popularity at international level. Both the world famous poets deal with humanity and nature which covers the universal matters. My research work has global relevance.

Both the poets deal mainly with humanism \& nature which has no boundary. Mirza Ghalib is famous for his moral and philosophical Ghazals. His most of the thoughts deal with our national issues namely, secularism, unity in diversity, feeling of brotherhood and tolerance and of course love for humanity. William Wordsworth's poetry also depicts human values which no doubt touches the emotions of everybody.

This project is interdisciplinary research work. It covers the ideas of both English and Urdu poets. So I am sure it is indeed a good research work which will open the new door of research for the students of Urdu literature. The new ideas and thoughts of both the literature will be mingled together and it is definitely going to be more knowledgeable and very much interesting. 